\title{
Solar Cell as Learning Multimedia to Improve Students' Scientific Literacy on Science and Nanotechnology
}

\author{
Eliyawati ${ }^{*}$, Yayan Sunarya², Ahmad Mudzakir² \\ ${ }^{1}$ International Program on Science Education, Faculty of Mathematics and Science Education, Universitas Pendidikan Indonesia \\ ${ }^{2}$ Department of Chemistry Education, Faculty of Mathematics and Science Education, Universitas Pendidikan Indonesia \\ *Corresponding Author. eliyawati@upi.edu
}

\begin{abstract}
This study aims to investigate solar cell as learning multimedia to improve students' scientific literacy on science and nanotechnology. Specifically, it describes learning design, the characteristic of developed learning multimedia and the description of learning activities using solar cell as learning multimedia to improve students' scientific literacy on science and nanotechnology. The method used in this research was Educational Research and Development that only consist of 3 stages. On the define stage, the research was conducted through literature review analysis, observation, and interview. On the design stage, the research was conducted through composing the instrument, developing solar cell as learning multimedia to improve students' scientific literacy on science and nanotechnology and composing teaching learning design. On the develop stage, the research was conducted through teaching learning activities using solar cell as learning multimedia to improve students' scientific literacy on science and nanotechnology. The research instruments were interview guideline, observation's sheet, judgment's sheet and questionnaire. Based on result and discussion, it can be concluded that learning design potentially improve students' scientific literacy. It is relevant with learning material and in accordance with the competence aspect, attitude aspect, and STL learning model. The characteristics of learning multimedia containing science and nanotechnology on solar cell context are: can be used classically, not individually, student-centered oriented, presenting the learning material using concept approach and context oriented, presenting the superiority of photochemistry solar cell with nanotechnology, visualizing the redox reaction concept on solar cell, and presenting the concept through context description. The learning multimedia is used in all STL learning phases. It can be used by teacher to deliver the material in almost all phases of learning, while student use it when teacher give them instruction.
\end{abstract}

Keywords Learning Multimedia, Nanotechnology, Science, Scientific Literacy, Solar Cell.

\section{INTRODUCTION}

Education plays very significant role in preparing the students to face the global competition. Therefore, the Indonesian educational quality in every aspect including Science Education must be routinely developed. Science Education plays a role in creating the qualified human resources. It can be developed through the developing of all scientific domains, in order to create the literate students. This literacy is further known as Scientific Literacy. Based on PISA's point of view (Programme for International Student Assessment), Scientific Literacy is defined as ability to use scientific knowledge, identify questions, and make conclusion towards the evidences to comprehend and help in making decision about the nature and human interaction with it (PISA, 2012).

Scientific Literacy is also defined as several assumptions, interpretation, construct, and perspective which are different with a term, how and what the term is formed (Laugksch, 2000). In fact, the level of the Indonesian children in scientific literacy is still on the basic level, compared with the scientific literacy level on International PISA (PISA, 2012). The result of 2012 PISA study showed that the ability of the fifteen years old Indonesian children on science was lower than others in the world. Indonesia was in the $64^{\text {th }}$ out of 65 participants who participated in the study. Based on the Organization for Economic Cooperation and Development (OECD) Assessment published on April 2012, showed that Indonesia was one level better than Peru. The average science's score of them was 383. In fact, OECD average of science's score was 501 (PISA, 2012). On the other side,

Received: 28 October 2017

Revised: 29 November 2017

Published: 30 November 2017 
the ability of scientific literacy on chemistry is also poor. It is caused by lots of contexts, contents, and unreachable process in basic chemistry concept (Sujana et al., 2014) As a result, the chemistry subject matter is not relevant with the students' point of view (Holbrook, 2005).

We should see those facts as the important information especially for educational stakeholders. The study of improving the Scientific Literacy is needed to restrict the gap between the science, science application and technology and evaluation including the social issue in the society (Mark \& Eilks, 2009). However, the students are lack of motivation to learn science and technology (Mark \& Eilks, 2009). The study of the most actual topics can be applied to attract students' interest and motivation (Ambrogi et al., 2008). One of the most actual topics today is nanotechnology (O'Connor \& Hayden, 2008). Nanotechnology can be easily comprehended by the students through scientific literacy, because it is the main important key in achieving the goal of science education (Gardner et al., 2010). The study of nanotechnology can bring positive result, not only cognitive aspect but also attitude towards science (Ambrogi et al., 2008).

The gist of nanotechnology study is understanding the phenomenon on the atomic, molecular and supramolecular level on the scale 1-100 $\mathrm{nm}$ to create and manipulate the instrument on learning material to get the new basic traits and function (O'Connor \& Hayden, 2008). Visualization is needed to understand the nano scale process (Ong, 1999; O'Connor \& Hayden, 2008). Computer is the instrument which can be used to visualize the nano scale process (Ong, 1999).

One of the advantages of using computer is creating invisible phenomenon and showing some things (Arsyad, 2011). Multimedia-based learning is very effective in helping the students visualize the dynamic chemistry process at the molecular level (Ardac \& Akaygun, 2004). Multimedia-based learning can improve the students' scientific literacy especially science content, context application and science process (Eliyawati, Sunarya, \& Mudzakir, 2017).

The chosen context of nanotechnology study is solar cell because it contains the concept, principle and law on the study of redox reaction. The context is adopted to push positive attitude and understand chemistry better. The definition of context itself is the situation which can help students to get concept, principles, law which can be expanded through an idea and practice (De Jong, 2008). The choosing content redox reaction is chosen based on consideration that: the evaluated concept must be relevant with the real daily-life situation, the concept is predicted to be still relevant in the next one decade, and it should deal with the process competence, the knowledge that not only rely on students' memory, but also on certain information (Hayat \& Yusuf, 2010).
Based on the background, the objective of this article is to investigate solar cell as learning multimedia to improve students' scientific literacy on science and nanotechnology. Specifically, this article describes learning design based on solar cell as learning multimedia to improve students' scientific literacy on science and nanotechnology, the characteristic of developed learning multimedia and the description of learning activities using solar cell as learning multimedia to improve students' scientific literacy on science and nanotechnology.

\section{METHOD}

The method used in this research was Educational Research and Development. This method actually consists of 4 stages (4D Model), they are define, design, develop and disseminate (Hermawan et al., 2017). However, only 3 stages were used in this research. It is appropriate with the objective of research which is investigating solar cell as learning multimedia to improve students' scientific literacy on science and nanotechnology. On the define stage, the research was conducted through literature review, contentstandard analysis, scientific literacy dimension analysis, observing several High Schools, interviewing several the $12^{\text {th }}$ grade Chemistry teachers, analyzing the result of the observations and interviews. On the design stage, the research was conducted through composing the instrument, developing solar cell as learning multimedia to improve students' scientific literacy on science and nanotechnology and composing teaching learning design. On the develop stage, the research was conducted through teaching learning activities using solar cell as learning multimedia to improve students' scientific literacy on science and nanotechnology.

The research instruments were interview guideline, observation's sheet, judgment's sheet and questionnaire. The preliminary interview guidelines and observation's sheet were used as the preliminary introductory research. Another observation's sheet was used to get the information directly about the students and teacher during the teaching learning process. The observation's sheet was appropriately arranged based on the Scientific and Technological Literacy (STL)-based learning's steps as stated on the lesson plan. The judgment sheet was used to get the information about the quality of the media. It was composed by using the indicator adapted from baker and King (Geissinger, 1997) and consisted of 26 statements. The last instrument used was questionnaire. It was used to get the information about the preliminary students' assumption toward multimedia and teachers' assumption after the multimedia were implemented.

\section{RESULT AND DISCUSSION}

Based on research, it is described the result data, data analysis, and discussion. The data obtained consist of: (1) The preliminary study; (2) Learning design based on solar 


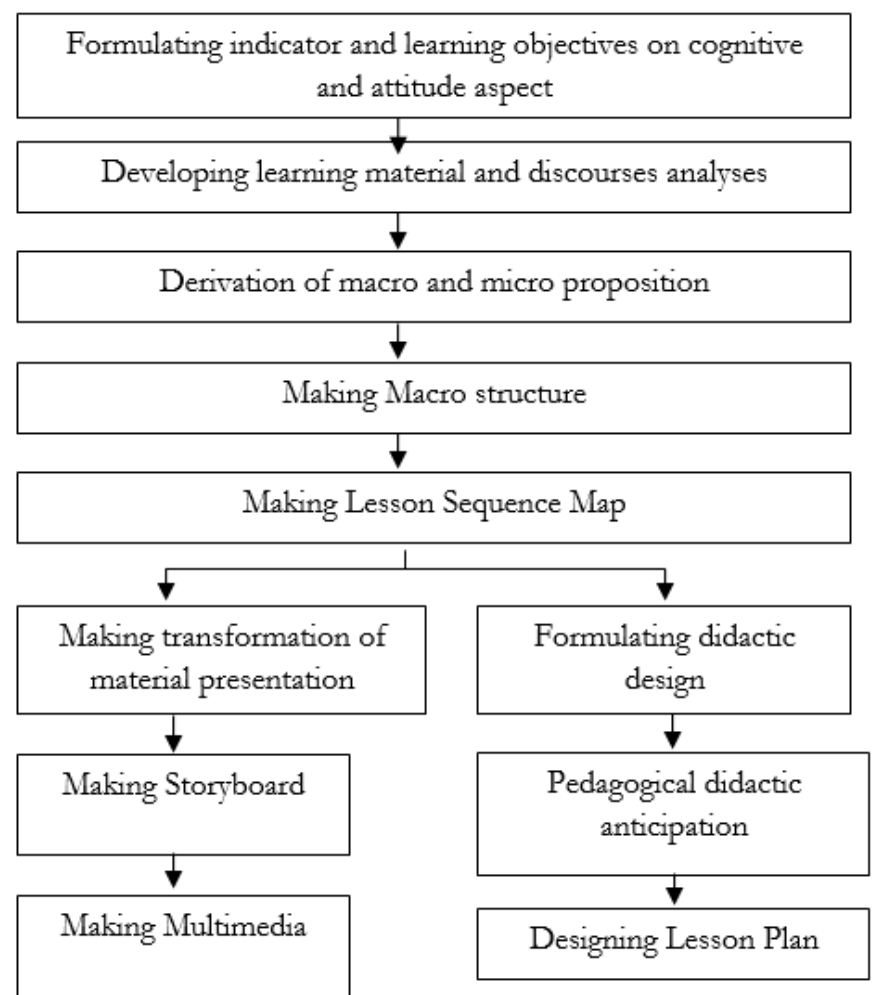

Figure 1 Development of learning design based on multimedia-based learning

cell as learning multimedia to improve students' scientific literacy on science and nanotechnology; (3) The characteristic of solar cell as learning multimedia to improve students' scientific literacy on science and nanotechnology; (4) The description of learning activities using solar cell as learning multimedia to improve students' scientific literacy on science and nanotechnology.

\subsection{The Preliminary Study}

The first step conducted was literature review about science and nanotechnology. The result shows that there is a science and nanotechnology application in the form of solar cell that has been developed and used in daily life. To describe the solar cell context, the content-standard of chemistry subject matter in senior high school was analyzed. Impact, the most appropriate chemistry topic with the solar cell context is redox reaction. The next step is content analysis about scientific literacy and analysis of scientific literacy dimension that includes: content, application context, process, and students' science attitude on redox reaction concept.

The observation was conducted to several senior high schools and interview to twelfth grade chemistry teachers at that school to obtain the evidence about students' scientific literacy about solar cell context on redox reaction content. The result of the observation and interview stated that none of the school developed the teaching learning process that can improve students' scientific literacy. Most of the school stated that the teaching learning process that had been being used was experiment which can only improve students' understanding (content) to reach for the standard score. All the teachers from that school stated that they were unfamiliar with redox reaction application containing science and nanotechnology on solar cell context. It becomes the reason why they have not developed the teaching learning process related with nanotechnology.

Several basic reasons that make teachers have not developed the teaching learning process related with nanotechnology to improve students' scientific literacy is because they have no effort to relate the technology development to the chemistry topic which is being learnt by students. The term of students' scientific literacy is also unfamiliar in Senior High School teacher. Besides that, there is no developed learning material which can improve students' science literacy. Based on those reasons, it is concluded that students' scientific literacy has not been integrated with chemistry teaching learning process in senior high school. It is supported by assessment study by PISA that shows science teaching learning in Indonesia does not improve students' scientific literacy.

\subsection{Learning Design Based on solar cell as learning multimedia to improve students' scientific literacy on science and nanotechnology}

Learning design is learning plan in the form of didactic situation series (relation between student and learning material) with pedagogical didactic anticipation (teacher action that will performed based on student's response 
prediction to the didactic situation created) in order achieving the expected competences (Suryadi, 2010). The learning design was developed and implemented by designing the lesson plan. Creating the design was conducted through several development phases that can be seen on Figure 1.

The first phase in making the learning design is formulating competence achievement indicator. The indicator itself is a competency achievement indicator which is a measurable and/or observable attitude to demonstrate the achievement of certain basic competencies that will be a subject matter assessment references (BSNP, 2007). The formulated indicator is formulated through the basic and standard competence analyses. Several indicators are determined to achieve that basic and standard competence.

The indicator on developed learning design consists of cognitive and attitude aspect. The formulated cognitivedomain indicator containing PISA competence aspect which emphasizes on students' thinking process on the main material discussed. The formulation of learning objectives on cognitive and attitude aspect tailored to the indicator on cognitive and attitude aspect that has been integrated with the chosen learning context which is Solar Cell.

The next phase is developing the Solar Cell learning material containing science and Nanotechnology using Solar Cell context. The learning material was developed in the form of basic text on discourses analyses. Discourses analysis is simplifying the material from its reference (textbook, journal, Internet). Discourses analysis was conducted by deleting or adding some words or phrases in order to make the text on the media easier to be understood by students (Setiadi \& Agus, 2001). The discourses production took in two phases which are the cognitive structure formation and the proposition formation. The result is the appropriate discourses with the defined learning objectives. The initial activity in this phase is composing and simplifying the text. The next, derivation of macro and micro proposition was conducted. After that, it is made the macro structure as in the Figure 1.

The defined learning objectives can be reached through STL learning phase which adopts Chemie im Kontext project learning phases (Nentwig et al., 2002: Holbrook, 2005). It is included contact, curiosity, elaboration, decision making, and nexus phase. The use of STL learning phase is to develop student thinking process that is faced with the problem: how can the Solar cell be used as an economical and environmentally friendly alternative source of electricity. That problem is presented in the curiosity phase and need to be answered to solve the problem in the decision-making phase. The STL learning phase is presented in the form of learning phases map called lesson sequence map.
Lesson sequence map is used as basis in making material presentation transformation and story board. Story board is text column, audio, and visualization with description about the content and visualization to produce the media. The last phase in developing the learning multimedia is multimedia production. Lesson sequence map is elaborated again with didactic design and pedagogical didactic anticipation. The definition of didactic design is learning plan in the form of didactic situation series (relation between student and learning material). Pedagogical didactic anticipation is an action that will be performed by teacher based on student's response prediction to the didactic situation created. Didactic design and pedagogical didactic anticipation is an initial analyzes when teacher will implement instruction in the form of certain model, approach and method on a particular subject matter.

Didactic design is further elaborated with pedagogical didactic anticipation. Pedagogical Didactic Anticipation (PDA) contains teacher anticipation based on possible student respond toward implemented didactic design. This PDA is made into a learning scenario containing the possible students' answer and questions, question anticipation, and teacher action based on expected students respond to teaching learning process.

Didactic design and PDA used as the basis for designing lesson plan. Lesson plan consist of several components which are subject matter, standard competence, basic competence, indicator, learning objective, learning material, time allocation, learning model, approach, and method, learning activity, references, and evaluation (BSNP, 2007). The lesson plan designed using STL model, concept approach and expository method. The reason of choosing that model, concept and approach is to make students easier to relate between science content, context and process. Students also have scientific attitude in order to improve their scientific literacy.

\subsection{The Characteristic of solar cell as learning multimedia to improve students' scientific literacy on science and nanotechnology}

Learning multimedia that has already made was as teaching aid in teaching learning process on solar cell context. The main principle of solar cell is redox reaction. For the first, the photons will stimulate ground state dyes to an excited-state condition. The dye at an excited-state condition will oxidize and leave as positive dye ion. The electrolyte mediator (iodide ion become tri-iodide ion) is needed for supplying electron to regenerate this oxidized dye so the dye will return back to the ground state condition. Finally, the electron will be captured by triiodide ion to form iodide ion (Prima et al., 2017).

The learning multimedia also contains science and nanotechnology because there is an explanation about the 
Table 1 Recapitulation of students' opinion at the preliminary phase

\begin{tabular}{ccccc}
\hline & & \multicolumn{2}{c}{ Score } & \\
\cline { 3 - 4 } No & \multicolumn{1}{c}{ Indicator } & $\begin{array}{c}\text { Average } \\
\text { Score }\end{array}$ & $\begin{array}{c}\text { Percen } \\
\text { tage } \\
\mathbf{( \% )}\end{array}$ & Category \\
\hline 1 & $\begin{array}{l}\text { Students; attitude } \\
\text { toward Chemistry }\end{array}$ & 3,02 & 75,6 & Good \\
2 & $\begin{array}{l}\text { Students; attitude } \\
\text { toward }\end{array}$ & 3,05 & 76,25 & Good \\
$\begin{array}{l}\text { Multimedia } \\
3\end{array}$ & $\begin{array}{l}\text { Students' opinion } \\
\text { about the } \\
\text { multimedia used }\end{array}$ & 3,14 & 78,54 & Good \\
Average & 3,07 & 76,8 & Good \\
\hline
\end{tabular}

use of nanoparticle $\mathrm{TiO}_{2}$ on solar cell as an anode and medium of electron current transmitter. The use of particle $\mathrm{TiO}_{2}$ is described through image and animation of how solar cell works. It is also described some aspects of concept using $\mathrm{TiO}_{2}$ as an electrode. The display of concept could be a text, an image, or an animation which are all describe in the way of getting the expected goal of teachinglearning process and 2009 PISA competence.

After multimedia has already been made, the expert's judgment is conducted. The result can be seen as shown on Figure 2. The average score on indicator of display design quality is $100 \%$, and $83.33 \%$ for interactivity which are considered very good, $80 \%$ and $79.2 \%$ for attractiveness and compatibility which are considered good (Figure 2). Some suggestion and recommendation for the researcher are also stated in this judgment. They are used as guidance in revising the multimedia. Several things that needed to revise are voice compatibility, animation, image some sentences, emphasizing an industry and adding some options on the students' exercise items. Generally, the media is good enough to be used.

After the multimedia has already been revised, the next step conducted is testing the multimedia at one of Senior High School in Bandung. Based on the test, the researcher revised the media in term of writing, answers, and redox reaction animation. The preliminary test is followed by 30 students who have learned about redox reaction. They fill the questionnaire provided. It is about the students' opinion about the developed multimedia.

The students' average questionnaire score is 3.07 equals $76 \%, 8 \%$ shows their good opinion about multimedia (Table 1). On this multimedia, some pages are designed in order to attract the students' intention and motivation to learn, so they could easily understand the teaching material. Those pages are:

1. Main page, contains the title, the information of learning multimedia maker, advisor, button that can be lined to related page. These main menu buttons consist of menu button, help button and exit button.

2. Menu page consists of some menu buttons, among others home, solar cell, potential electrode, application and evaluation.

3. On home page, there are teacher's instruction which state about competence standard/basic competence, indicator of cognitive aspects and attitude that must be pursued by the students after using learning multimedia.

4. On home page, there is also students' guidance about the students' goal of learning this multimedia.

5. The rest page, there are about the series of materials, which are going to be explained based on the steps of STL. The material concept explained consists of some phases, they are contact, curiosity, elaboration, decision making, nexus and assessment that can be linked in accordance with the material.

The learning multimedia is also made based on the sequence of teaching- learning process phases that are, contact, curiosity, elaboration, decision making, nexus and assessment. The first phase of multimedia based teaching is contact that showed the video of electrical energy in a district. Solar cell is chosen the source of electrical energy to supply the need of electricity. On this phase, the students were expected to be motivated to learn the teaching material about the need of electrical energy. On this phase also, solar cell and the use of nanoparticle on solar cell was explained. The second phase is curiosity. On this phase the

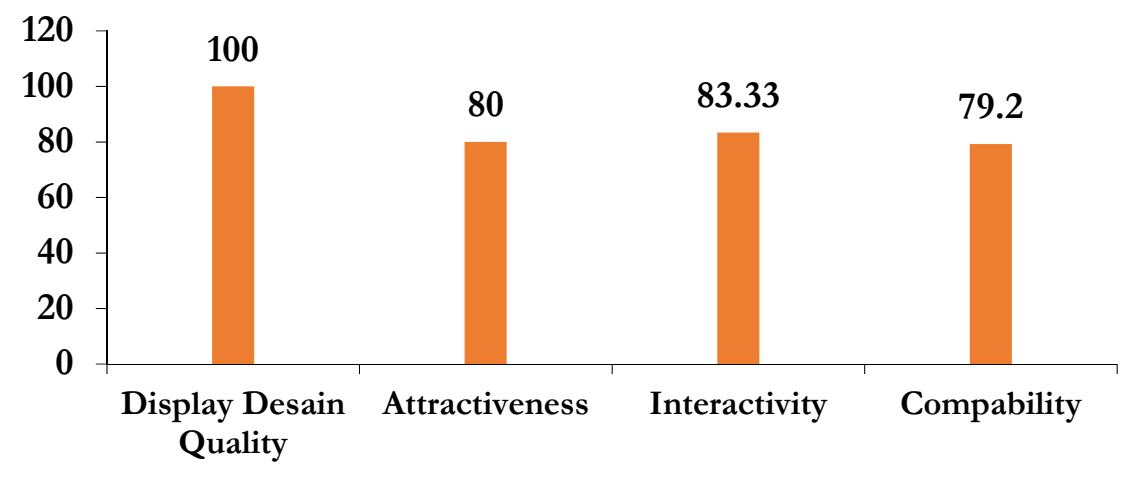

Figure 2 Expert Judgment recapitulation 

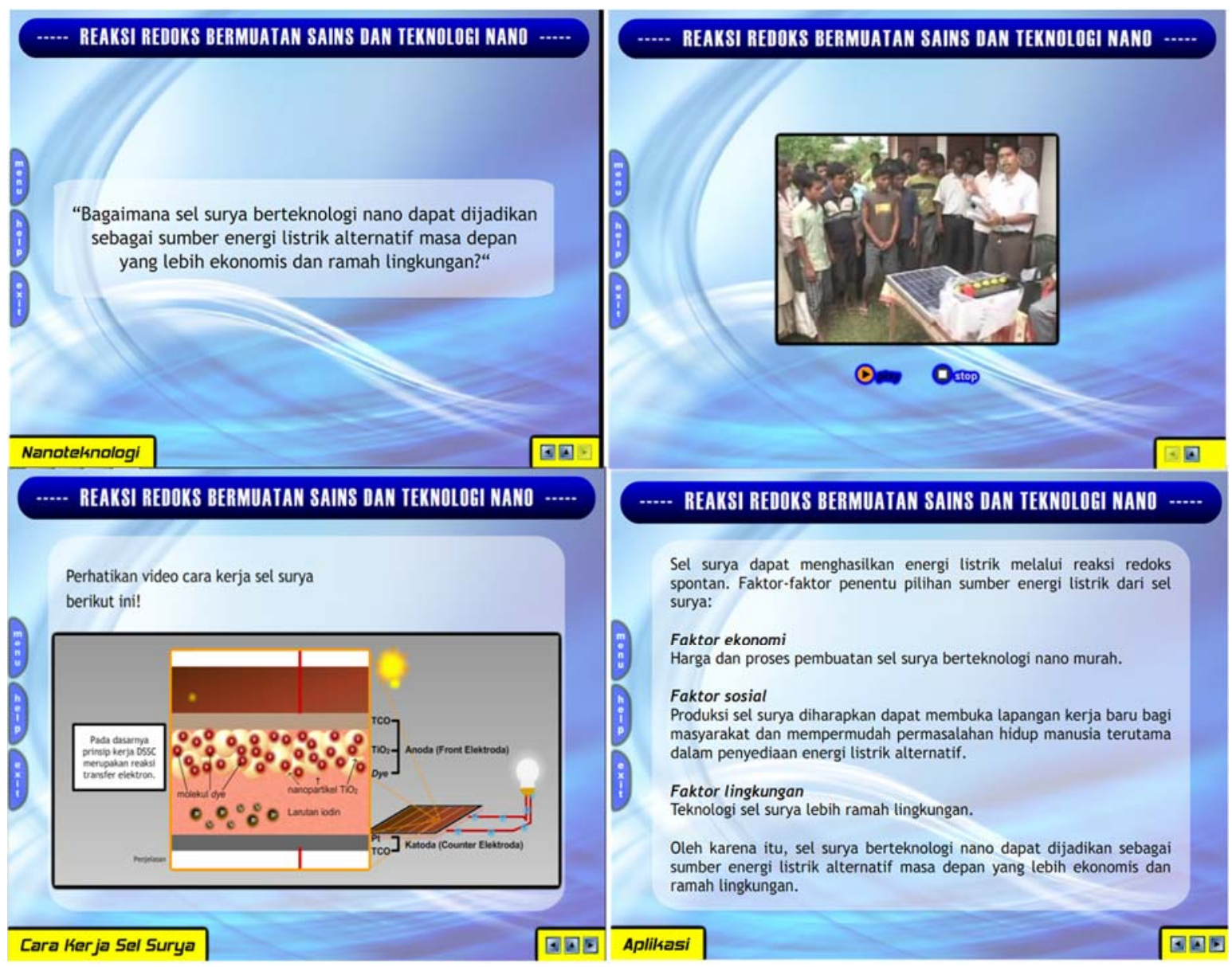

Figure 3 Example of learning multimedia display

question that can be attracted the students' curiosity was given. The third phase is elaboration which figured out many animation, image, video and simulation about the concept which is used to explore and place the students' concept on the first phase through solar cell context. The examples of the display of learning multimedia can be seen on Figure 3.

The fourth phase is decision making that presents the question on the curiosity phase in order to have students make the decision about some decisive factors of choosing solar cell as the source of electricity. There are three decisive factors, among others economic factor (it is cost less and easy produces), social factor (solar cell production is expected to open a new field of work for society and facilitate them to look for the alternative source of energy), and environmental factor (Solar cell energy is environmentally friendly). Therefore, it can be used as the future alternative source of electricity which is economically cheaper and environmentally friendly. The next phase is nexus or concept development phase. It figures out the application of redox reaction in daily life as dry cell battery or accumulator.

The additional phase is assessment. It presents 10 multiple choice items to practice with. The item was designed in such a way that student could only be able to answer the questions once. If they give the correct answer, they will get 10, if they give the wrong answer, they will get zero. The wrong answer has to be correctly answered, thus they can do the next items. Based on the result data of implementation and questionnaire given to the students and teacher about the implementation of learning multimedia, generally they give positive response. It can be seen through their average score on their preliminary trial as 3.07 or $76.8 \%$ (categorized good), and the result of questionnaire after implementing their average score, that is 3.12 or $78.05 \%$ (categorized good), so is the teacher's average score and percentage of questionnaire, that is 4.44 or $85.88 \%$ (categorized very good). Therefore, some characteristics of learning multimedia containing science and nanotechnology on solar cell context as follows:

1. This multimedia can be used in the class, it cannot be used for individual learning.

2. It is student-centered oriented which involves teacher as a central role in learning.

3. Presenting the learning material using concept approach and context oriented thus students are able to formulate and build the concept through the questions, statement 
and exercise simulation deals with the use of $\mathrm{TiO}_{2}$ nanoparticle on solar cell.

4. Present the advantages of photochemistry solar cell with nanotechnology as an alternative electrical energy resource which is cheaper and environmentally friendly.

5. Visualizing the redox reaxtion concept occurs on solar cell which is abstract through video, animation and image.

6. Presenting the concept through context explanation in accordance with scientific literacy learning phases.

\subsection{The Description of learning activities using solar cell as learning multimedia to improve students' scientific literacy on science and nanotechnology}

\section{Contact Phase}

On this phase, issues in the society were raised or finding out some events that occur around the students and relating them with the teaching material, thus realize how important the material is. The need of electricity was shown. When the video was playing, all the students paid attention to the video, then they all at once gave a response that the tool which can produce electricity on the video is solar cell. On the next contact phase, it was explained about the solar cell that using nanoparticle as its component. When the students were asked about the definition of nano, initially almost all students did not respond to the question, however a few minutes later, a student gave a response that nano is measurement unit. After that, other student explained the definition of nano and nanotechnology. All students paid attention to the explanation carefully. They felt they do understand about it and have no further question on this contact phase. Then they were able to identify the transformation of energy occurs on Solar cell, it is the light energy that transforms into electricity. On this phase, the students' enthusiasm has not been seen clearly. Therefore, the teacher plays a very important role to motivate them by telling something interesting about solar cell. On this phase, the students were able to identify the description of energy transformation on Solar cell.

\section{Curiosity Phase}

After knowing that there is energy transformation on Solar cell from light energy into electricity, the next phase is delivering questions in which the students' knowledge of Chemistry is needed to arouse the students' curiosity. The way teacher guided the students' curiosity is by giving question through multimedia: "How solar cell containing Nano can become the future alternative source of energy which economically cheaper and environmentally friendly?" Most of them were in silence and had no idea about the question asked. Then, students answer that Solar cell is very important as alternative energy resource when teacher gave them question about the importance of it. To answer the curiosity question, teacher asked students to find out the answer after they learn about the material in the next phase which is elaboration.

\section{Elaboration Phase}

The exploration and the concept formation were conducted through learning multimedia where students attained the concept from multimedia with teacher guidance. In this phase, there is the time where students listened to the teacher explanation on multimedia and there is also the time where students conducted individual learning and conduct discussion guided by teacher. In fact, some of students didn't pay attention to the teacher explanation and they were busy with their own multimedia. The multimedia should be disabled as long as teacher was explaining the material to make the situation better. The observer had a very important role in paying attention to the students' activity. By using the multimedia, the learning time was shorter. It is in line with statement that the learning allocation time is shorter when we use the media (Arsyad, 2011). Based on the observation, there is the interaction between students and multimedia, students and teacher, students and students in the teaching learning process. It is proved when students can answer the questions and analyze the animations on multimedia.

\section{Decision Making Phase}

In this phase, students were directed to be able to make decisions based on the evidence obtained at the elaboration phase. Students should be able to make a decision about " How solar cell containing Nano can become the future alternative source of energy which economically cheaper and environmentally friendly?". The shamed student to express their opinion was the obstacle in this phase. The role of teacher is to encourage and guide students in order to express their opinions. Finally, most of the students expressed their opinions together based on the most students' opinion, and teacher guides students to the correct answer. At the end, students and teacher made a conclusion based on results of discussions and concepts that had been understood to answer curiosity questions. One of the students asked to repeat the conclusion. In this phase, the role of multimedia was showing the students' conclusion after they discuss it with teacher and showing the determinant factors, which make the solar cells was chosen as alternative energy sources.

\section{Nexus Phase}

The process of taking the basic concepts from the learning material and its application to the other context (decontextualization) was conducted. It means that the same problem is given in different context but it needs the same concept in solving the problem (Nentwit et al., 2002). This phase is conducted in order to have more applicative 
and meaningful knowledge out of the learning context. The application of redox reaction in daily life is dry cell battery and accumulator.

\section{Assessment Phase}

The last phase is assessment. It is intended to know the improvement of students' scientific literacy after experiencing scientific literacy and technology based learning. The assessment was conducted by giving the posttest which the items are the same with the pretest. The assessment was also conducted when students were conducting the exercise on the multimedia. Most of the students answered the question correctly. The role of multimedia is to know the students' achievement towards the learning material that has been discussed.

According to the observation data, generally the implementation of learning has been in line with STL learning phases. The contact phase, it was aroused the issue about daily life which is related to the redox reaction, so the students realized to the importance of learning material. The issue and problem were showed through video about the need of electrical energy (solar cell). The curiosity phase, it was asked the question that can stimulate students' curiosity about the relation of the problem with the redox reaction material. Elaboration phase, delivering the spontaneous reaction in Solar Cell that could generate on the electrical energy. Decision making phase, the questions from the curiosity phase arouse and discussed actively with enthusiasm to make decision. Nexus phase, it was explained the redox reaction on application which battery and accumulator. In this phase, students were very interested in answering the questions. The assessment phase, given the exercise and posttest.

\section{CONCLUSION}

Based on result and discussion, it can be concluded that learning design based on solar cell as learning multimedia on science and nanotechnology potentially improve students' scientific literacy. This design is based on didactic design and pedagogical didactic anticipation which is relevant with learning material and in accordance with the competence aspect, attitude aspect, and STL learning model. The characteristics of learning multimedia containing science and nanotechnology on solar cell context are: (1) can be used classically, it cannot be used for individual learning, (2) student-centered oriented, (3) presenting the learning material using concept approach and context oriented, (4) presenting the superiority of photochemistry solar cell with nanotechnology, (5) visualizing the redox reaction concept on solar cell, (6) presenting the concept through context description in accordance with scientific literacy learning phases. Learning multimedia containing science and Nanotechnology on Solar Cell Context is used in all STL learning phases. It can be used by teacher to deliver the material in almost all phases of learning, while student use it when teacher give them instruction.

\section{REFERENCES}

Ambrogi, P., Caselli, M., Montalti, M., \& Venturi, M. (2008). Make sense of nanochemistry and nanotechnology. Chemistry Education Research and Practice, 9(1), 5-10.

Ardac, D., \& Akaygun, S. (2004). Effectiveness of multimedia-based instruction that emphasizes molecular representations on students' understanding of chemical change. Journal of research in science teaching, 41(4), 317-337.

Arsyad, A. (2011). Media pembelajaran. Jakarta : PT Raja Grafisindo Persada.

De Jong, O. (2008). Context-based chemical education: How to improve it?. Chemical Education International, 8(1), 1-7.

Eliyawati, Sunarya, Y., \& Mudzakir, A. (2017). Enhancing students' science literacy using solar cell learning multimedia containing science and nano technology. In AIP Conference Proceedings (Vol. 1848, No. 1, p. 060015). AIP Publishing.

Gardner, G., Jones, G., Taylor, A., Forrester, J., \& Robertson, L. (2010). Students' risk perceptions of nanotechnology applications: implications for science education. International Journal of Science Education, 32(14), 1951-1969.

Geissinger, H. (1997). Educational software: Criteria for evaluation. In Proceedings of ASCILITE (Vol. 97, pp. 219-225).

Hayat, B., \& Yusuf, S. (2010). Mutu Pendidikan. Jakarta: Bumi Aksara.

Hermawan, H., Siahaan, P., Suhendi, E., \& Samsudin, A. (2017). Promoting collaboration skills on reflection concept through multimedia-based integrated instruction. In AIP Conference Proceedings (Vol. 1848, No. 1, p. 050009). AIP Publishing.

Holbrook, J. (2005). "Making Chemistry Teaching Relevant". Chemical Education International Journal. 6(1), 1-12.

Laugksch, R. C. (2000). Scientific literacy: A conceptual overview. Science education, 84(1), 71-94.

Marks, R., \& Eilks, I. (2009). Promoting Scientific Literacy Using a Sociocritical and Problem-Oriented Approach to Chemistry Teaching: Concept, Examples, Experiences. International Journal of Environmental and Science Education, 4(3), 231-245.

Nentwig, P., Parchmann, I., Demuth, R., Graesel, C., \& Ralle, B. (2002). Chemie im Kontext, from situated learning in relevant contexts to systematic development of chemical concepts. In second IPN_YSEG Symposium on context-based curricula, October (pp. 10-13).

O'Connor, C., \& Hayden, H. (2008). Contextualising nanotechnology in chemistry education. Chemistry Education Research and Practice, 9(1), 35-42.

Ong, E. W., Pizziconi, V. B., \& Ramakrishna, B. L. (1999). Interactive nano-visualization for science and engineering education. Journal of Materials Education, 21(1/2), 27-40.

BSNP. (2007). Standar Proses untuk Satuan Pendidikan Dasar dan Menengah. Badan Standar Nasional Pendidikan.

PISA, O. (2012). Results in focus. 2014-02-17]. http://mmw, oecd. org/pisa/keyfindings/pisa-2012-results-o-verview, pdf.

Prima, E. C., Hidayat, N. N., Yuliarto, B., \& Dipojono, H. K. (2017). A combined spectroscopic and TDDFT study of natural dyes extracted from fruit peels of Citrus reticulata and Musa acuminata for dye-sensitized solar cells. Spectrochimica Acta Part A: Molecular and Biomolecular Spectroscopy, 171, 112-125.

Setiadi, R. \& Agus, A. (2001). Dasar-Dasar Pemrograman Software Pembelajaran. Bandung: Jurusan Pendidikan Kimia FPMIPA UPI.

Sujana, A., Permanasari, A., Sopandi, W., \& Mudzakir, A. (2014). Literasi Kimia Mahasiswa PGSD Dan Guru IPA Sekolah Dasar. Jurnal Pendidikan IP A Indonesia, 3(1).

Suryadi, D. (2010). Menciptakan proses belajar aktif: Kajian dari sudut pandang teori belajar dan teori didaktik. Bandung: Tidak diterbitkan. 